\title{
Hated without a reason - Contending with issues of human sexuality in a South African ecclesial context: A case study
}

Author:
Graham A. Duncan ${ }^{1}$
Affiliation:
'Department of Church
History, Christian Spirituality
\& Missiology, College of
Human Sciences, University
of South Africa, Pretoria,
South Africa
Corresponding author:
Graham Duncan,
profgrahamduncan@gmail.
com
Dates:
Received: 06 Oct. 2020
Accepted: 15 Mar. 2021
Published: 09 June 2021
mort phone or
mow to cite this article:
to read online.
Duncan, G.A., 2021, 'Hated
without a reason -
Contending with issues of
human sexuality in a South
African ecclesial context: A
case study', HTS Teologiese
Studies/Theological Studies
77(4), a6347. https://doi.
org/10.4102/hts.v77i4.6347
Copyright:
C 2021. The Authors.
Licensee: AOSIS. This work
is licensed under the
Creative Commons
Attribution License.

The mainline churches in South Africa are in turmoil internally as a result of divisions arising out of issues related to human sexuality. These issues have serious implications for these churches, church families within them, and the relationship of these churches with one another and with the state. There is little open space for debate as discussions are hampered by a variety of theological perspectives on the authority of scripture, some of which are fixed and absolutised. This is a matter of justice for all those involved. This research article seeks to analyse the issues involved theologically and in terms of church polity, with a view of clarifying possibilities and options for a resolution of the distress and pain caused within and between members of the Christian family using the transnational context of the Uniting Presbyterian Church in Southern Africa as a case study. The concepts of critical solidarity and critical distance will be used to clarify relationships within the relevant contexts. This article is interdisciplinary and embraces the fields of Church History or Polity, Practical Theology, Missiology and Systematic Theology.

Contribution: This paper seeks to analyse issues of human sexuality within a South African Christian denomination with particular attention to the matter of justice.

Keywords: Committee on Human Sexuality (CHS); fundamentalism; justice; homosexuality; Uniting Presbyterian Church in Southern Africa.

\section{Introduction: Justice}

The issue of human sexuality is a matter of justice denied to lesbian, gay, bisexual, transgender, intersex, and questioning (LGBTIQ) people in South African churches. I work with the following definition provided by Brueggemann (1986):

In biblical faith, the doing of justice is the primary expectation of God, for God is indeed a 'lover of justice'
(Ps 99:4). The way the Bible thinks about justice is: justice is to sort out what belongs to whom, and return
it to them. Such an understanding implies that there is a right distribution of goods and access to the
sources of life. We control what belongs to others long enough, we come to think of it as rightly ours, and
to forget it belonged to someone else. So the work of liberation, redemption, salvation is the work of
giving things back. Justice concerns precisely a right reading of social reality, of social power, and of social
good. (p. 5)

He explains the implications of this definition:

One of the misfortunes in the long history of the church is that we have mistakenly separated love of God from love of neighbor and always they are held together in prophetic poetry. (p. 5)

Covenant members who practice justice and righteousness are to be active advocates for the vulnerable and the marginal and the people without resources, and that then becomes the way to act out and exhibit one's love of God.

The love of God, therefore, gets translated into love of vulnerable neighbours. And the doing of justice is the prophetic invitation to do what needs to be done to enable the poor and the disadvantaged and the neglected to participate in the resources and the wealth of the community.

Furthermore, injustice is the outcome of having skewed neighbourly processes, and therefore, some are put at an unbearable disadvantage.

And the gospel invitation is that people intervene in that to correct those mistaken arrangements (Brueggemann 2011). 
With respect to the topic of human sexuality what does justice require of us where gay people have been deprived of genuine love, their dignity, respect (of self and others), and an authentic and meaningful role in the church? Surely, it implies the restoration of justice, leading to the assertion of the dignity of all God's creatures, respect from others and within themselves, and an authentic role in church and society as we are 'all one person in Christ Jesus' (Gl 3:28), for 'It is through faith that you are all sons of God in union with Christ Jesus' (G1 3:26). Faith is the prime qualifier for union with Christ. The Uniting Presbyterian Church in Southern Africa (UPCSA) is one denomination, which is struggling with the implications of justice in relating to the debate regarding human sexuality.

\section{The Uniting Presbyterian Church in Southern Africa}

Regarding justice, the Confession of Faith of the UPCSA (2007:2.4) has the following to say:

1.3 Human society is capable of degrees of justice, and human beings of great altruism, heroism and self-sacrifice. Yet both societies and individuals are capable also of appalling brutality and degradation. The most just society is radically flawed with injustice, and our noblest deeds and highest virtues with individual and group egoism, pride and self-interest. Group and individual interests distort even how we judge between right and wrong.

20.3 Everyone has a God given dignity and a right to be treated with respect and protected from violence and abuse, no matter their gender, age, race, social status sexual orientation, ...

26.2 Justice is at the heart of peace.

This provides the context for the UPCSA discussion on the issue of human sexuality because it is also true that the church can be guilty of 'appalling brutality and degradation'. This is nowhere truer than in the issue of human sexuality.

Just prior to the union which brought the UPCSA into being in 1999, the General Assembly of the Presbyterian Church in Southern Africa (PCSA) (one of the partners in the union negotiations) received a report in 1998 from its ad hoc Committee on Human Sexuality (CHS), which is focussed largely on homosexuality. This report noted the tension between the 'liberal' views of the committee and the vast majority of respondents to a request to respond to the report (PCSA 1999:184-207). Whilst supporting care for the homosexual, there was no compromise on the view that homosexuality was a sin (PCSA 1999:183). A minority view considered the issue to be more complex. The matter was carried over to the first General Assembly of the UPCSA. Until this time, the other partner in the negotiations, which brought the UPCSA to birth, the Reformed PCSA, had never considered the matter; it was not a significant issue. It was agreed in the 2000 General Assembly that all documentation related to this matter be distributed to all sessions (UPCSA 2000:290).

In 2001, the Priorities and Resources Committee recommended that the CHS 'consider moral and pastoral issues related to human sexuality as they apply to the policy of the UPCSA and our faith' (UPCSA 2001:48). No report was forthcoming but the Assembly recorded a decision arising out of a notice of motion.

In light of the recent decision of the constitutional Court regarding the adoption of children by same-sex couples and in light of the pending judgement regarding same-sex marriages, the General Assembly instructs the CHS to formulate a position on:

- Homosexual practice

- The marriage of homosexuals

- The adoption of children by such couples

To be considered at the 2003 General Assembly (UPCSA 2002:482).

This was strange as the General Assembly had seemed to have stated its position on the first bullet point and consequently the other two points. The committee did not respond to its remit, and no report was submitted in 2003. The lack of submission of reports indicates a lack of urgency in the matter or perhaps unwillingness to raise a contentious issue.

Subsequently, an ecumenical perspective was introduced when a notice of motion was accepted regarding the Committee on Human Relations (CHR), which was instructed to present Assembly in 2004 with a report for the Assembly:

- To establish an official standpoint on ministers and office-bearers within our denomination who are selfacknowledged practising homosexuals;

- To rule (in the light of the $\mathrm{m}$ acceptance of ministries laid down in the Church Unity Commission Agreement) whether an appointment to one of our churches of a minister from one of the other denominations in the Church Unity Commission (CUC) who is a selfacknowledged practising homosexual would be acceptable to the UPCSA $(2003: 97,107)$.

Perhaps, it is worth noting at this point that the issue of human sexuality was exercising the mind of all of the mainline denominations in South Africa at this time (UPCSA 2004:221). The notice of motion was restricted to 'self-acknowledged practising homosexuals'. It was probably aware that to go further with regard to unacknowledged homosexuals was going to be a protracted and complex legal and moral minefield. In 2004, the CHR presented a report comprising a number of significant points, trying to offer an inclusive approach, amongst which it was indicated that there was a diversity of perspectives, a lack of agreement concerning biblical hermeneutics, a pastoral dimension that eschewed involvement with homosexual persons and a divisiveness resulting from the issue:

While understanding the desire of many within the UPCSA for certainty/absolutes, the Committee believes that in this issue we must avoid the temptation to 'fast forward to the end of the movie' for the sake of our impatience or our need for less ambivalence and more security. (UPCSA 2004:221) 
The committee advocated a process involving an "'encircling approach", in which space is created for people to be exposed to and explore, the relationship between Christianity and homosexuality without a predetermined outcome' (UPCSA 2004:221). However, it was recognised that this approach required commitment from 'people on every side of the debate' (UPCSA 2004:222). Positive steps were agreed on with the intention of bringing the matter to a conclusion at the 2006 General Assembly (UPCSA 2004:451-452). Here, we note a more positive approach, which continued a degree of pastoral consideration and justice for homosexuals by acknowledging the need for them to be involved in the process.

Furthermore, the report named the demon in the entire debate, the matter which prevented any authentic progress the matter of the authority of scripture and biblical hermeneutics. The other significant issue that the UPCSA tradition affirms in this regard is freedom of conscience, which is interpreted variously. However, the UPCSA of Confession of Faith (2007) places limits here:

Conscience itself must be transformed by being made captive to that Word [of God]; for Christ, not conscience is the ultimate judge of what is right or wrong. (p. 10.5)

The Presbytery of Thekwini proposed an apparently conciliatory statement, with the intention of being a 'constructive and affirming statement of unity' (UPCSA 2005:27). However, they were stating the terms of conciliation, which involved a departure from the UPCSA Confession of Faith in a conservative direction.

At the same meeting, the Executive Commission received an extensive report from the CHS (UPCSA 2005:75-88), which was sent down to presbyteries for discussion and report (UPCSA 2005:241, 253). This report focussed on terminology; psychological, biological and sociological research; a multifactorial approach and the biblical context. It concluded by tacitly acknowledging the lack of justice (UPCSA 2005):

[...W]e can all be more loving, more compassionate and more understanding both to gay and lesbian people we meet and deal with in our congregations and to those in our church who have different views to our own in the matter. Whatever your own view may be, there is one thing we all ought to regard as nonnegotiable as we struggle with this issue, it is the unity of the body of Christ. (p. 86)

This report appears to have superseded the Thekwini Presbytery motion, which was referred to the Doctrine, Ethics and Discipline Committee. It was considered to be divisive because it only drew from the PCSA doctrinal standards without reference to the Reformed Presbyterian Church. It was further considered to be 'an attempt to preempt, or worse manipulate the outcome of the game' (UPCSA 2006:102). The recommendation was to 'facilitate a revision and a reformulation of the petition'.

When the Human Sexuality committee reported, the UPCSA (2006:531) endorsed several principles:
- Proposal 1: 'The Word of God in Scripture is our only final rule of faith and life' [as stated in the Preamble to The Faith of the Church (Interim Manual of Law and Procedure, Appendix A) and is, therefore, determinative for our position on homosexuality and our attitude towards people of different sexual orientations.

- Proposal 2: There are, however, different interpretations of just what Scripture says and implies on the issue of homosexuality, and we acknowledge this diversity without calling into question the integrity and faith of those with opposing viewpoints.

- Proposal 5: The context for the discussion on homosexuality is the whole area of human sexuality. There needs to be a basic consistency in the way sexual ethics are applied to sexual relationships.

- Proposal 6:... Human sexuality includes all that we are as human beings, and although it is closely related to biological sex and procreation, they are not to be simply equated. The distinctions that give expression to our sexuality, our fundamental maleness or femaleness, run deeper than the procreative function. Sexuality is, at the very least, biological, psychological, cultural, social and spiritual. It is as much of the mind as the body and of the community as the person. Human sexuality is the most complete way of total giving of oneself to another. It is the most personal, intimate and sacramental outward expression, which God has given. To be a person is to be a sexual being. Sexuality then belongs to the mystery of the image of God.

This was collated into a Statement on Homosexuality to which the assembly decisions were attached. Again, this indicated a failure of love on the part of members of the UPCSA. These included the following:

- To call its members prayerfully to consider whether they have failed to show Christian love towards any homosexual persons in the past and repent thereof

- To condemn all forms of discrimination and abuse on the basis of sexual orientation as sinful

- To condemn all forms of sexual promiscuity

- To exercise a prophetic, healing and caring ministry when dealing with questionable sexual behaviour

- To urge all its members to deepen their understanding of the issue of homosexuality in dialogue with homosexual Christians through the study of Scripture and using insights from medical science and psychology (UPCSA 2006:610)

- To confirm the definition of Christian marriage set out by the Executive Commission in 2005 where the Executive Commission affirmed that:

- 8.2 The Executive Commission instructs all marriage officers affiliated with the UPCSA to remain faithful to the definition of marriage and to exercise pastoral compassion and sensitivity in their dealings with all who approach the Church for assistance with marriage.

These decisions were the result of intense discussion and compromise made during the course of the General Assembly, 
with the intention of avoiding a serious and irreparable division in the UPCSA. The fundamentalist camp was aiming for the Assembly to declare a one-size-fits-all view of homosexuality which was a contravention of its historical and traditional broad church stance. The decisions relate largely to personal responses to the issue.

Decision no. 6 was confusing because of the lack of a definition of 'questionable' sexual practice. Part of decision no. 7 had already been supported by agreement on a proposal to investigate the matter inter alia relating to Mendelian Genetic Inheritance Theory (UPCSA 2006:547). This was performed and reported in 2008 (UPCSA 2008:357). However, it was a vain hope that the main thrust of the decision would be carried out as most of the commissioners had apparently already made up their minds on the matter in a negative manner.

Decision no. 8 was problematic, as no one had challenged the definition of Christian marriage at this stage. However, the sub-text was that homosexual relations posed a threat to marriage. No evidence was presented to support this view, nor has it been since. It is difficult to understand how people deciding against heterosexual marriage actually threaten the institution of marriage. The phrase 'exercise pastoral compassion and sensitivity in their dealings with all who approach the Church for assistance with marriage' was a euphemism for refusing to celebrate gay marriage. However, it is not possible to prescribe the outcome of a pastoral process if it is initiated and participated in with integrity. Again, these terms were ambiguously couched in order to present a united front.

In 2008, the focus of the CHR report was '... we desperately need to keep the things we share in priority over the things we do not'. This arose out of a consideration of three options: a dogmatic approach, avoidance and a 'stepped' option. The committee favoured the last option. In acknowledgement of the decision: 'The issues surrounding homosexuality are varied and complex and require journey and dialogue with those affected' (UPCSA 2008:355). Here was the seed of an approach based on justice for homosexual Christians in the UPCSA. No one had ever asked them for their experiences and opinions - an act of injustice through omission.

The CHR also provided a comment on the recently passed Civil Unions Bill (Act 17 of 2006), which is applicable to both heterosexual and homosexual couples (whose union may be registered as a civil partnership or as a marriage). This means that ministers who are marriage officers may not automatically marry homosexual couples. This matter is determined by denominations who are required to opt in to permit their ministers perform civil partnerships or marriages, whilst the Act 'retains the right of individuals to refuse to do so on the grounds of conscience, religion or belief' (UPCSA 2008:356). This precludes UPCSA ministers from celebrating such unions and is an act of injustice towards those whose consciences are offended. However, the CHR noted in 2016 that (UPCSA 2016):
[L]aws and social norms within South Africa have to some extent been reshaped, most notably the Civil Unions Act of 2007. This has started a new dialogue on the issue both within Churches and between the Churches and wider society that continues today. (p. 389)

A further substantial report was presented to the General Assembly in 2016 with a strong focus on justice drawing on external South African sources for support. It is based on a minority submission (referred to as MS2004 in the report) of the Presbytery of the Western Cape to the South African Law Reform Commission in 2004 (UPCSA 2016:389-399). One issue that is dealt with is the injustice dealt out to homosexuals on the basis of their sexual orientation. It reports on Archbishop Desmond Tutu's assertion that churches have demonstrated prejudice against homosexuals causing substantial psychological damage, and this is supported by Gaum and Gaum (2010):

Gay people are still the object of twisted jokes, jeering looks and talk behind their backs. That must wound - 'and the hurt goes very deep'. (p. 29)

Desmond Tutu highlighted the essential injustice as early as 1996 when he spoke out against the injustice perpetrated by Christians who shared a common baptism. As author of a Forward in a book by Bennet and Preston (1996), he lamented:

It is a 'cri de coeur' from the hearts of persons we have first accepted as baptized fellow Christians, members together with us all in the body of this Jesus Christ, wherein as a result of that baptism there is neither Jew nor Greek, male nor female, free nor slave - there is a radical equality. [Gl 3:28]

And then we spurn them, we shun them, because we are all caught up in an acknowledged or a tacit homophobia and heterosexism. We reject them, treat them as pariahs and push them outside the confines of our church communities, and thereby, we negate the consequences of their baptism and ours.

We make them doubt that they are the children of God, and this must be nearly the ultimate blasphemy. We blame them for something that it is becoming increasingly clear they can do little about. Someone has said that if this particular sexual orientation were, indeed, a matter of personal choice, then gay and lesbian persons must be the craziest coots around to choose a way of life that exposes them to so much hostility, discrimination, loss and suffering. To say this is akin to saying that a black person voluntarily chooses a complexion and race that exposes him - or herself - to all the hatred, suffering and disadvantages to be found in a racist society. Such a person would be stark raving mad (Tutu 1996:ix).

The injustice of church treatment of homosexuals is a matter of concern.

Furthermore, the 2016 report highlighted the South African term 'corrective rape', resulting in physical attack, rape and murder. Russell (2004:30) had added his critique that the church has been responsible for cruel and inhuman treatment of homosexuals. MS2004 stated: 
That historically the Church's stand on human rights has often been poor. Its general attitude to homosexual people in particular, and its treatment of them, has fallen appallingly short of Jesus' fundamental command to love people of every kind. ... The tragically much higher incidence of suicide among homosexuals has been blamed on continuing social hostility, and the attitude of the Church and Christians has often been at the root of this: the rejection and hostility in western society as a whole is largely rooted in the Christian tradition. Many homosexuals have as a result turned their backs on the Church. In many cities, like Cape Town, homosexual Christians have felt it necessary to start their own churches. (UPCSA 2016:389)

In addition, it is not possible to evaluate the damage caused to families of gay children whose parents have been faithful and committed members of churches who reject their children, who have left the church in solidarity with their offspring or by causing family division. This clearly exemplifies the degree of injustice experienced not only by families but also by their loved ones. It is acknowledged that more recently, some denominations have begun to recognise the levels of human angst experienced and have begun to change their attitudes with regard to significant scriptural passages 'in the light of God's Word of love and grace that became incarnate in Jesus Christ' (UPCSA 2016:390). This has been reflected in theological scholarship both within South Africa (e.g. eds. Germond \& De Gruchy 1997; Judge et al. 2008; Russell 2004) and beyond.

\section{These views are corroborated by Palm (2019):}

[T] he current lack of safe, inclusive spaces for LGBTIQ people in many local church congregations in South Africa. This should be seen in the light of a formal conservative backlash at denominational levels (West et al. 2016; Gunda 2017). This leads to hiding, exclusion and trauma for many LGBTIQ Christians seeking to worship at 'mainstream' churches and often a retreat into 'separatist' gay church spaces. Progressive congregations have experienced disillusionment in the light of recent refusals by senior church leaders in multiple denominations to move forwards significantly on this issue. This raises the need for concrete theological approaches from below to be better identified, nurtured and documented within existing local congregations. (p. 3). [Palm's research included contributions from the Presbyterian tradition, see p. 2]

However, other forces were at work where homophobia was sublimated under the guise of caring:

Whilst experiences of outright theological rejection of LGBTIQ persons were noted by some, more interviewees noted a more complex harmful theology through the approach of many churches to say, 'we love you BUT ...' reiterating a theology where they feel God says 'I love you but you are rubbish' by 'accepting' or tolerating LGBTIQ orientation but not its embodied practice, by embracing only the single celibate individual but not the whole person in the midst of their concrete loving relationships. (Palm 2019:13)

The 'BUT' is the critical ' $\mathrm{NO}^{\prime}$ in the discourse. This exemplifies the negative sub-text of many unexpressed attitudes of the perpetrators towards homosexuals, which are experienced differently by the victims.
Furthermore, the $\mathrm{CHR}$ report noted the tensions arising within the UPCSA resulting from the threats of potential divisions. The Moderator of General Assembly reminded the denomination that three points were basic to our consideration of this matter:

- All people are made in the image of God, and Christ died for all of us.

- We need to listen to the voices of the marginalised and excluded in our existing fellowship, as well as to Scripture before making any decisions.

- The Church needs to be open to the Spirit's transforming power in thinking about this issue (UPCSA 2016:390).

By far, the longest section of the 2016 report focussed on the interpretation of scripture (UPCSA 2016:392-398). This reiterates material that had been presented previously. However, it began with a section on Interpreting the Bible and raised issues relating to changing attitudes to understanding how the Word applies to homosexuality in the same way it has changed its views on subjects, such as slavery. It comments (UPCSA 2016):

The Church's understanding in this area has also benefitted from listening to the voices of those who have suffered exclusion and injury from traditional interpretations. This has made people more careful in examining what the Bible actually says. It has opened up space for dialogue that respects the fact that Christians may understand Scripture and what it implies for our behaviour differently at different times. (p. 397)

This section ends with the following declaration:

Thus for many the criterion for an ethic of homosexual relationships, namely, whether the relationship is a genuinely caring, loving, consensual and faithful one of permanent commitment, in which neither party abuses, manipulates or exploits the other either physically or emotionally. (UPCSA 2016:397)

This supports the view that there should be no abuse from either within or beyond homosexual relationships. There was no reference to this ethic with regard to heterosexual relationships.

Palm's (2019) research corroborates the use of the Bible for such interpretation:

[... I]n literalist ways was noted by many using the justification that the 'Word of God is perfect'. It played a strong role in churches holding theologies of exclusion particularly the use of the seven 'terror' texts, despite their theological deconstruction. Interviewees noted that this is despite the rejection by these churches of similar biblical texts on issues such as slavery and genocide. The Bible is used indirectly to endorse paradigms of hierarchical domination and submissive obedience as 'Godordained' within multiple biblical texts and stories. The Bible has long been abused to serve those in power across many hierarchical intersections; black/white, male/female, rich/poor but also the straight/queer binary. Interviewees note that this becomes a justification for the treatment of LGBTIQ people as second-class citizens, presenting difference not as to be celebrated but pushed down. It often ties into the treatment of women as second class, using the Bible and the name of God to perpetuate patriarchy and police gender binaries. (p. 130) 
Here again, we can note the use of scripture as a significant source of injustice. This is exacerbated (Palm 2019) by:

$[\ldots T]$ he use of ecclesial power, especially by pastors, to impose an interpretation onto the whole congregation and to negate the creation of a space where congregants were encouraged to think critically for themselves. This was described as a need to move away from models of 'one guy with one word' who aimed to create 'cut and paste copies' of Christians. This model was seen by some interviewees to encourage a sheeplike following in ways that negated the critical thinking required by all to move forwards. It was suggested that ecclesial power often corrupts and that pastors may need to take an oath to. (p. 14)

The outcome of the 2016 UPCSA CHR report was as follows:

- The General Assembly in preparation for discussion and decision on the issue at the next General Assembly in 2018:

- (1) Instructs all Presbyteries to distribute the document on Christian Ethics and Same-Sex Unions in the Appendix amongst all their commissioners, to set a time to discuss the report, and to report their reactions and findings to the convener by the end of 2017, and (2) instructs all Sessions likewise to discuss the report (M). (UPCSA 2016:425)

In response to this, the Presbytery of eGoli (UPCSA 2016:545-547) submitted an overture to the 2016 General Assembly, in which it reminded the Assembly that it had, in 2006, committed the UPCSA to continued engagement, study and prayer over this contentious issue (homosexuality) because any decision on homosexuality could not be divorced from the whole area of human sexuality, and there, therefore, needs to be a basic consistency in the way sexual ethics are applied to all sexual relationships. This would be one of the ways to avoid the perpetration of injustice. It further noted that these issues had not been raised since 2008, and a great deal has happened in the intervening period regarding Human Sexuality and Civil Unions. In 2018, once again at the General Assembly, a summary of research and work carried out on the topic was tabled for the Commissioners.

The Presbytery of eGoli took up the issue in Zambia and Zimbabwe, which was being used as an argument to prohibit same-gender unions, and further noted that this was irrelevant as neither country had laws that prohibited samegender relationships. And if they have such laws, how would that affect the argument when South Africa did have such laws? The argument had to be consistent. If same-gender unions were prohibited in Zambia and Zimbabwe because of the law, surely the same argument would apply in South Africa anyway.

The Presbytery of eGoli overtures the General Assembly of the UPCSA to take into consideration that the issues of samegender relationships and civil unions are those that have the potential to divide the Church, given that this matter is much more complex than the simple matter of whether or not it accepts same-sex unions. It devolves into theological understanding, including the Constitution of the country in which we reside. It would be irresponsible to expect the General Assembly of the UPCSA to make a ruling that will alienate one party or another.

All these issues should be addressed again in a manner that assist the making of the decisions that are long overdue, and which create the space for all parties on both sides of the continuum in this debate, to freely practise their convictions whilst maintaining mutual respect for one another within the Church (UPCSA 2016:547).

After an acrimonious debate in which the convener of the $\mathrm{CHR}$ resigned, after he was jeered by some commissioners, the General Assembly resolved that:

- Ministers of the UPCSA are forbidden to officiate at and to bless same-sex civil unions and to communicate this to all Presbyteries of the denomination

- In order to preserve the sanctity of Christian marriage, no minister may officiate at civil unions.

The General Assembly instructed the Clerk of Assembly to write a letter to the Rev Dr Robert Steiner, apologising for the rude and cruel behaviour it displayed by cheering and clapping when he announced his resignation as the Convener of the Human Sexuality Task Team, and urged him to reconsider his resignation (UPCSA 2016:573).

Liberty of opinion and freedom to choose were the casualties in this decision in the name of a reductionist approach to scripture where the Word of God was reduced to mere words.

\section{A way forward}

Following the example of Jesus, Burridge (2008) affirms:

Unfortunately, all too often those who do New Testament ethics today end up [either] ... teaching a rigorist ethic with extreme demands which seems condemnatory and alienates people - or having an open acceptance and being accused of having no ethics at all! Seeking to follow Jesus in becoming both 'perfect' and 'merciful' as God is perfect and merciful (cf Mt 5:48 with Lk 6:36) is not an easy balance to maintain, but one which is vital if we are to be properly Biblical. (p. 171)

This expresses the irresolvable dilemma the church faces today. Grimsrud (2001) follows Burridge in the need to find and pursue a middle way:

$[\ldots W]$ e would do well to devote more energy to trying to find common ground in relation to biblical interpretation. I do not believe the differences are so much based on different understandings of biblical authority as they are simply on different people finding different meanings in the texts. Hence, in theory we should be able to progress toward some common ground. (p. 14)

In order to do so, we need to have good faith with one another in attempts to grapple with the Bible seriously. Perhaps, the 
biggest challenge of this study is to make the effort to understand one another before launching into our critique. Rather than treating this controversy as an argument to win or lose, we would do much better to think more in terms of a puzzle to solve, and that we all have a contribution to make to such a solution. No one is benefitting from the acrimony of the current impasses that the churches find themselves.

Progress can, therefore, only be made on matters of theological interpretation by operating from a perspective of mutual respect and regard, and in solidarity with the gospel. The gospels are a source of theology that provides a way of systematising our belief and operates to assist us in our deeper understanding of the Good News of Jesus Christ. As the world looks on with amazement at our conflicts in this regard, we should be shamed into creating and affirming solidarity for the sake of the gospel. This can only have its source in God's love and our love for others agape - a going out of and from the self in the service of others; by contrast, Tillich's definition of love is the 'drive towards the unity of the separated' (Tillich 1955:50). A drive is a powerful impulse that impels us outwards towards those in need. This is not primarily a matter of choice but primarily a response to God who comes to us under the same impulse energised by the Holy Spirit. Perhaps, a relevant question all need to consider what is it that 'drives' us in this matter?

This specific issue is receiving significant attention globally at this time, even seen as at risk of fracturing the worldwide church and has been problematically portrayed at times using an African or Western static binary. The South African experience on LGBTIQ issues is, therefore, important because of its unique positioning, situated within a historically complex set of intersectional oppressions of race, colonialism and gender that have been, at least partially, shaped by religion (Palm 2019:3).

Palm's (2019:6) study identified four components from responses given in this area of shaping an inclusive church ethos:

- A transformative ecclesiological vision

- Normalising welcome and belonging

- Developing models of celebration and accompaniment

- Building a sense of being united across diversity.

Here, we have the possibility of acceptance (Tillich's synonym for forgiveness) that is needed by all of those concerned about matters relating to human sexuality, perpetrators and victims, as expressed by Tillich (1955):

You are accepted. You are accepted, accepted by that which is greater than you, and the name of which you do not know; perhaps you will find it later. Do not try to do anything now; perhaps later you will do much. Do not seek for anything; do not perform anything. Simply accept the fact that you are accepted! If that happens to us, we experience grace. After such an experience we may not be better than before. But everything is transformed. In that moment, grace conquers sin, and reconciliation bridges the gulf of estrangement. And nothing is demanded of this experience, no religious or moral or intellectual presupposition, nothing but acceptance. (pp. 161-162)

This is because of a failure of love, which is a challenge for mission 'constrained by Jesus' love' (2 Cor 5:14) (Bosch 1991:286-291, 514, 519).

\section{Acknowledgements Competing interests}

The author declares that he has no financial or personal relationships that may have inappropriately influenced him in writing this article.

\section{Author's contributions}

G.A.D. is the sole author of this research article.

\section{Ethical considerations}

This article followed all ethical standards for research without direct contact with human or animal subjects.

\section{Funding information}

This research received no specific grant from any funding agency in the public, commercial or not-for-profit sectors.

\section{Data availability}

Data sharing is not applicable to this research article as no new data were created or analysed in this study.

\section{Disclaimer}

The views and opinions expressed in this article are those of the author and do not necessarily reflect the official policy or position of any affiliated agency of the author.

\section{References}

Bennett Alexander, M. \& Preston, J., 1996, We were baptized too: Claiming God's grace for lesbians and gays, Westminster John Knox Press, Louisville.

Bosch, 1991, Transforming mission: Paradigm shifts in theology of mission, Orbis, Maryknoll, NY.

Brueggemann, W., 1986, 'Micah 6:8: What does the lord require of you? But to do justice, and to love kindness, and to walk humbly with your God?', in W. Brueggemann, S. Parks \& T.H. Groom (eds.), To act justly, love tenderly, walk humbly: An agenda for ministers, pp. 5-28, Paulist Press, New York, NY.

Brueggemann, W., 2011, What is justice?, viewed 17 October 2019, from https:// www.readingtheology.com/walter-brueggemann-what-is-justice.

Burridge, R.A., 2008, 'Being biblical?: Slavery, sexuality, and the inclusive community', HTS 64(1), 155-174. https://doi.org/10.4102/hts.v64i1.8

Gaum, F. \& Gaum, L., 2010, Praat verby grens, Interplay Books, Pietermaritzburg.

Germond, P. \& De Gruchy, S. (eds.), 1997, Aliens in the household of God, David Philip, Cape Town.

Grimsrud, T., 2001, "The "homosexuality" debate: Two streams of biblical interpretation', in C. Norman Kraus (ed.), To continue the dialogue, pp. 1-22, Pandora, Kitchener.

Gunda, M.R., 2017, Silent no longer! Narratives of engagement between LGBTI groups and the churches in southern Africa, Report: The Other Foundation, Johannesburg.

Judge, M, Manion, A. \& De Waal, S. (eds.), 2008, To have and to hold: The making of same-sex marriage in South Africa, Fanele (Jacana), Braamfontein.

Palm, S., 2019, From exclusion to embrace: Re-imagining LGBTIQ belonging in local South African church congregations, Unit for Religion and Development Research, University of Stellenbosch, Stellenbosch. 
Presbyterian Church in Southern Africa (PCSA), 1999, Papers and proceedings, PCSA Johannesburg.

Russell, D., 2004, The bible and homosexuality: What is the spirit saying to the churches?, CPSA, Cape Town.

Tillich, P., 1955, The shaking of the foundations, Charles Scribner's Sons, New York, NY.

Tutu, D.M., 1996, 'Forward', in M.B. Alexander \& J. Preston (eds.), We were baptized too: Claiming God's grace for lesbians and gays, pp. ix-x, Westminster John Knox Press, Louisville, KY.

Uniting Presbyterian Church in Southern Africa (UPCSA), 2000, Papers and proceedings, UPCSA, Johannesburg.

Uniting Presbyterian Church in Southern Africa (UPCSA), 2001, Papers and proceedings, UPCSA, Johannesburg.

Uniting Presbyterian Church in Southern Africa (UPCSA), 2002, Papers and proceedings, UPCSA, Johannesburg.
Uniting Presbyterian Church in Southern Africa (UPCSA), 2003, Papers and proceedings, UPCSA, Johannesburg.

Uniting Presbyterian Church in Southern Africa (UPCSA), 2004, Papers and proceedings, UPCSA, Johannesburg.

Uniting Presbyterian Church in Southern Africa (UPCSA), 2005, Papers and proceedings, UPCSA, Johannesburg.

Uniting Presbyterian Church in Southern Africa (UPCSA), 2006, Papers and proceedings, UPCSA, Johannesburg.

Uniting Presbyterian Church in Southern Africa (UPCSA), 2007, Manual of faith and order of the UPCSA, UPCSA, Johannesburg.

Uniting Presbyterian Church in Southern Africa (UPCSA), 2008, Papers and proceedings, UPCSA, Johannesburg.

Uniting Presbyterian Church in Southern Africa (UPCSA), 2016, Papers and Proceedings, UPCSA, Johannesburg. 